ADDIN, Volume 13, Number 1, February 2019

\title{
Immunology Pedagogical Psychology of Pesantren Kindergarten: Multicase Study at Pesantren Kindergarten in Yogyakarta
}

\section{Suyadi}

Universitas Ahmad Dahlan Yogyakarta, Indonesia

suyadi@fai.uad.ac.id

\section{Abstract}

Normatively, children's education is the responsibility of the family. But when families experience disharmony, even broken home, children's education prone to be abandoned. When a modern school has not been able to maximally accommodate broken home children, Early Childhood Pesantren becomes the best alternative choice. The purpose of this research is to find the best alternative education for broken home children in the modern era. This research was conducted throughout 20172018 at Baiquniyah Early Childhood Pesantren Yogyakarta. This research was using the qualitative approach, while data collection techniques were observations, interviews, and documentation data analysis was done in descriptive, interpretative, and comparative. The results show that Baiquniyah Early Childhood Pesantren Yogyakarta can be the best alternative choice. This is because the Baiquniyah Early Childhood Pesantren Yogyakarta is able to bring the children closer to their parents psychologically, even when they are biologically separated. This condition has implications for the increase of pedagogical immunity, in which children are not easy to stress and depression, thus comfortable in studying at 
pesantren. The results of this study break Finkelhor's findings which state that children who are cared for by caregivers will often experience violence, but not so in Islamic Boarding Schools in general and in the Baiquniyah Early Childhood Pesantren Yogyakarta in particular.

Keyword: Early Childhood Pesantren, Islamic Education, Learning Psychology, Pedagogical Immunity.

\section{Abstrak}

PSIKOLOGI PAEDAGOGIK IMUNOLOGI PADA TK PESANTREN: STUDI MULTI-KASUS DI TK PESANTREN YOGYAKARTA. Secara normatif pendidikan anak menjadi tanggung jawab keluarga. Tetapi ketika keluarga mengalami disharmonis bahkan broken home, pendidikan anak terancam telantar. Ketika sekolah modern belum mampu menampung anak-anak korban broken home secara maksimal, Pondok Pesantren Kanak-kanak menjadi pilihan alternatif terbaik. Tujuan penelitian ini adalah menemukan pendidikan alternatif terbaik bagi anak-anak korban broken bome di era modern. Penelitian dilakukan sepanjang tahun 2017 di Pesantren Kanak-kanak Baiquniyah Yogyakarta. Pendekatan penelitian ini adalah kualitatif. Teknik pengumpulan data dengan observasi, wawancara, dan dokumentasi. Analisis data dilakukan secara deskriptif, interpretatif dan komparatif. Hasil penelitian menunjukkan bahwa Pesantren Kanak-kanak Baiquniyah Yogyakarta dapat menjadi alternatif pilihan terbaik. Hal ini disebabkan karena Pesantren Kanak-kanak Baiquniyah Yogyakarta mampu mendekatkan anak dengan orang tuanya secara psikologis meskipun mereka terpisah secara biologis. Kondisi ini berimplikasi pada meningkatnya imunitas paedagogis, yakni tidak mudah stres dan depresi sehingga nyaman belajar di pesantren. Hasil penelitian ini mematahkan temuan Finkelhor yang menyatakan bahwa anak-anak yang diasuh oleh pengasuh akan sering mengalami 
kekerasan, namun tidak demikian di pesantren pada umumnya dan Pesantren Kanak-kanak Baiquniyah Yogyakarta pada khususnya.

Kata Kunci: Pesantren Kanak-kanak, Psikologi Pendidikan, Imunitas Paedagogis.

\section{A. Introduction}

Recent research on pesantren has been more concerned with its existence as a life skills ${ }^{1}$ as well as indigenous of traditional Islamic education institutions in Indonesia ${ }^{2}$ including salaf or traditional Pesantren curriculum, ${ }^{3,}$, in the face of modernity. ${ }^{5}$ The related research is sufficiently comprehensive to cover, from the fundamentals such as Pesantren leaders named by Kyai, santri (student) ${ }^{6}$ and traditional book containing of Islamic teaching and learning, ${ }^{7}$ Pesantren management toward globalization, ${ }^{8}$ curriculum in modern era, ${ }^{9}$ integrates Islamic schooling (madrasah) and modern schools, ${ }^{10}$ national education policy ${ }^{11}$ to the development of

1 M.M. Siti Ma'rifah, "Pesantren Sebagai Habitus Peradaban Islam Indonesia", Jurnal Penelitian 9, no. 2 (2015): 347-366.

2 J.M. Asmani, "Pesantren Sebagai "Kiblat" Pendidikan dan Pengetahuan Indonesia”, Jurnal Islamic Review 1 (2016): 59-84.

3 Edy Kusnadi, A.A. Kadir Sobur, "An Islamic Boarding School: a Study of AlMubarok Al-Islam within the Social Changes of Seberang", Addin 11, no. 1 (2016): 101130.

4 A. Fauzi, "Abuya Dimyati's Idea in Development of Traditional Islamic Studies and Spiritualistic: Islamic Studies at Pondok Pesantren Cidahu Pandeglang", Addin 11, no. 1 (2016): 131-156.

5 A.S. Rifai, "Pembaharuan Pendidikan Pesantren dalam Menghadapi Tantangan dan Hambatan di Masa Modern", Jurnal Inspirasi 1, no. 1 (2017): 21-38.

6 A.M. al-Azhar, "Pesantren: Santri, Kiai, dan Tradisi", Ibda: Jurnal Kebudayaan 12, no. 2 (2014): 109-118.

7 Ali Akbar, "Metode Pembelajaan Kitab Kuning di Pondok Pesantren Daarun Nahdhah Thawalib Bangkinang", al-Fikra: Jurnal Ilmiah Keislaman 17, no. 1 (2018): 21-32.

8 N.R. Hayati, "Manajemen Pesantren dalam Menghadapi Dunia Global", Tarbawi 1, no. 2 (2015): 97-106.

9 A. Saifuddin, "Eksistensi Kurikulum Pesantren dan Kebijakan Pendidikan", Jurnal Pendidikan Agama Islam 3, no. 1 (2015): 208-234.

10 M. Yusuf, "Dinamika Integrasi Pesantren dan Sekolah Dalam Pendidikan Kontemporer di Indonesia”, al-Murabbi 3, no. 2 (2017): 178-191.

11 Yedi Purwanto Badrun, "Pesantren dalam Kebijakan Pendidikan Indonesia", Jurnal Lektur Keagamaan 15, no. 1 (2017): 233-272. 
Pesantren-based character education. ${ }^{12}$ While the phenomenon of modernity as an impact caused by the efforts of Pesantren toward modernity itself has not been much touched by researchers such as international Pesantren, ${ }^{13}$ entrepreneurial Pesantren, ${ }^{14},{ }^{15}$ and others partially.

This study was carried out to continue what previous researchers did as mentioned above but with different accents, highlighting the symptoms of phenomenal modernity in Pesantren, especially the rise of childhood Pesantren model, ${ }^{16}{ }^{17}{ }^{18}$ such as Pesantren Tahfidz Qur'an Anak Yanbu'ul Qur'an, Kudus Jawa Tengah, Pesantren Tahfidz Qur'an Anak Al-Munawwir Krapyak, Komplek Q, Yogyakarta, Pesantren Rodlotul Qur'an Semarang, Pesantren Tarbiyatul Wildan Muftaul Ulum Jakarta, Early Childhood Pesantren Assalim Tengerang Jawa Barat, Early Childhood Pesantren Tarbiyatul Wildan Nihayatul Amal, Cirebon, Jawa Barat, Early Childhood Pesantren Darunnajah Cipinang, Jawa Barat, and so on.

The Early Childhood Pesantren that became the focus of this research was Baiquniyah Yogyakarta. This Pesantren is considered unique because most of its early childhood santri (someone who follows Islamic religious education in pesantren, usually settled in the place until the education is complete) are came from broken home families. Of course, the challenges, obstacles, and barriers

12 U Saepullah, Pendidikan Karakter Berbasis Pesantren (Jakarta: Naga Kusuma Media Kreatif, 2016).

13 A. Kurniawan, "Manajemen Kerjasama Lembaga Pendidikan Islam dengan Masyarakat: Studi Kasus Pondok Pesantren Alam Internasional Saung Balong Al-Barokah Cisambeng Palasah Majalengka", Holistika 15, no. 1 (2014): 161-178.

14 Azel Raoul Reginald, "Kewirausahaan Sosial pada Pondok Pesantren Sidogiri Pasuruan”, Jesit 1, no. 5 (2014): 333-345.

15 C. Chotimah, "Pendidikan Kewirausahaan di Pondok Pesantren Sidogiri Pasuruan", Inferensi: Jurnal Penelitian Sosial Keagamaan 8, no. 1 (2014): 115-136.

16 S. Muntomimah, "Model Pendidikan Karakter Anak Usia Dini di Pondok Pesantren Al-Hikam Kota Malang”, JIP 7, no. 1 (2017): 43-51.

17 Fatimah Binti Su'aidah Hanur, "Dari Pesantren untuk PIAUD: Relevansi Pemikiran al-Ghazali dengan Prosesi Pendidikan Islam Anak Usia Dini di Era Modern", Annual Conference for Muslim Scholars Kopertais Wilayah IV Surabaya (ANCOMS) 2017: 898908.

18 Umi Musaropah, "Pemberdayaan Masyarakat dalam Penyelenggaraan Pendidikan Anak Usia Dini Berbasis Pesantren”, As-Sibyan: Jurnal Pendidikan Guru Raudlatul Athfal 1, no. 2 (2016): 177-85. 
in educating broken home children-even more so in really young children - are much harder than educating the children from the harmonious family. This is more interesting because some of the early childhood santris testimonies mentioned that they are more comfortable in the pesantren than in their own homes. In other words, they are more comfortable with ustady (teacher) and Kyai (pondok pesantren leaders who have the wide knowledge of Islam) than their own parents.

The problem, is it right to children at this early age entering the pesantren already? This question is important because when the children go to the pesantren, automatically they are "separated" from their parents because pesantren learning system is 24 hours. In fact, in some hadiths of the Prophet Muhammad, especially the Hadiths of at-Tirmidhi no. 1.283 and al-Hakim mentioned that parents are forbidden to separate children from their mothers. Therefore, the Early Childhood Pesantren seem less in line with the two Hadiths. The worst impression is Early Childhood Pesantren perceived as a "seclusion" place for broken home children.

From the psychological perspective, early childhood still needs more parental hugs. If the affection needed is unfulfilled, it can result in the children's psychological condition, in which children susceptible to depression and at risk of behavioral problems (ref). If Baiquniyah Early Childhood Pesantren is played a role in accommodating children who are separated from their parents, then Early Childhood Pesantren seemed irrelevant to modern psychological theories. Ki Hadjar Dewantara also stated who the most responsible for children's education is family. The existence of Early Childhood Pesantren as if eliminates the families' role in educating children. Thus, the problem of this research is the existence of the Baiquniyah Early Childhood Pesantren which is normatively-theologically incompatible with the Hadiths of the Prophet Muhammad SAW, and theoretically incompatible with the view of modern psychology. 
Prior to clarifying the problems mentioned above, it is necessary to look into existing studies, whether associated with the Early Childhood Pesantren as well as the children psychological condition when separated from parents and following the learning program at Pesantren. A serious research on the Early Childhood Pesantren is research conducted by Muhyidin about the history of the development of Early Childhood Pondok Pesantren Gebang Putih Sukolilo Surabaya (1994-2015). Another research was conducted by Supriadi on leadership in Islam ${ }^{19}$ and Kasfun Anwar Us about Kyais leadership in the democratic pesantren of Jambi. ${ }^{20}$ Similar research was conducted by Siti Chusniyah and Muh. Yasir Alimi about women's leadership in pesantren. ${ }^{21}$

The research that examines the children psychological condition when separated from parents and follows the learning program at pesantren are: Spiritual Intelligence of Early Childhood at Early Childhood Pondok Pesantren Bantul Yogyakarta, ${ }^{22}$ Santris Motivation to go to pesantren. ${ }^{23}$ And also Ade Hidayat research that identified the santris peaceful personality (peaceful in pesantren) in Madrasah Aliyah (Mualimin) Pesantren Persis 19 Bentar Garut. ${ }^{24}$

Based on the literature study on previous studies above, it can be concluded that no one has questioned the establishment of the Early Childhood Pesantren in theological normative associated with badanah (prohibition to separate children from parents) Hadiths. The research related to the children psychological condition, when separated from parents and follow pesantren learning program, has

19 Supriadi, "Leadership in Islamic Education Institution", Leadership 21, no. 3 (2014): 198-205.

20 Kasful Anwar Us, "The Leadership of Kyai in Islamic Boarding School: a Study of Islamic Boarding School in Jambi”, Leadership 22, no. 1 (2001): 88-95.

21 Siti Chusniyah and Moh. Yasir Alimi, "Nyai Dadah: the Elasticity of Gender Roles and Life", Jurnal Komunitas 7, no. 1 (2015): 112-17.

22 Ali Amran, "Pengembangan Kecerdasan Spiritual Anak Usia Dini Berbasis Edutainment di TK Qurrota A'yun Pondok Pesantren Anak Bantul Yogyakarta", Universitas Islam Negeri (UIN) Sunan Kalijaga Yogyakarta, 2015.

23 Nelpa Fitri Yuliani, "Hubungan antara Lingkungan Sosial dengan Motivasi Belajar Santri di Pesantren Madinatul Ilmi Islamiyah”, Spektrum PLS 1, no. 2 (2013).

24 Ade Hidayat, "Peaceful in Pesantren: the Involvement of Santri's Peaceful Environment and Personality", al-Ta'lim Journal 24, no. 2 (2017): 79-92. 
been done but in general, such as the children's motivation to go to pesantren and children's anxiety toward bullying behavior.

This research is clarifying the existence of Baiquniyah Early Childhood Pesantren related hadanah (prohibition to separate children from parents) Hadiths and children psychological condition when being separated from parents and participate in pesantren learning program. The hypothesis constructed in this research was the existence of Baiquniyah Early Childhood Pesantren in response to the social reality of abandoned children who biologically separated from parents, and then bring children to psychologically closer to parents through the pesantren learning program.

\section{B. Discussion}

\section{Historical Normativity of Baiquniyah Early Childhood Pesantren}

Indonesia has a unique form of traditional Islamic education, which is Pondok Pesantren (Pontren). Pesantren in Indonesia exist since the $17^{\text {th }}$ century, ${ }^{25}$ and continues to grow with various classifications, such as salaf pesantren, traditional pesantren and modern pesantren. ${ }^{26}$ Although pesantren continues to experience the social and cultural change in the current global-millennial era, pesantren is able to maintain universal Islamic values. ${ }^{27}$ Even Steenbrink's thesis that predicted pesantren would disappear as it turns into madrasab (regular Islamic school) and schools do not happen. ${ }^{28}$ This shows that within pesantren, there are values of modernity so as to be able to face the challenges of times. ${ }^{29}$

25 Khorij, "Pendidikan di Pesantren: antara Mempertahankan Tradisi dan Kebutuhan Modernisasi”, Manbaj 4, no. 1 (2011): 139.

26 Suyadi dan Sutrisno, "A Genealogycal Study of Islamic Education Science at the Faculty of Ilmu Tarbiyah dan Keguruan UIN Sunan Kalijaga", Al-Jami'ab: Journal of Islamic Studies 56, no. 1 (2018): 29-58.

27 Azumardi Azra, Pendidikan Islam: Tradisi dan Modernisasi Menuju Milineum Baru (Bandung: Mizan, 2012).

28 Karel A. Steenbrink, Pesantren Madrasah Sekolah (Jakarta: LP3ES, 1986).

29 Hermansyah Putra, "Pondok Pesantren dan Tantangan Globalisasi: Upaya Pondok Pesantren Musthafawiyyah Purba Baru Sumatera Utara dalam Mempertahankan Sistem Tradisional" (Disertasi: Universitas Islam Negeri Sunan Kalijaga Yogyakarta, 2009). 
The development of pesantren in Indonesia is very dynamic and progressive. ${ }^{30,31}$ In the past, pesantren consisted only of Kyai, santri, kitab kuning (traditional books containing Islamic religious lessons), pondok (dormitory) and mosques; ${ }^{32}$ but now pesantren has been developed with ustadz, caretakers, libraries, laboratories, even the internet. In the early days of pesantren, it was only for adolescents and adults, nowadays pesantren is also reserved for children, even early childhood as modern schools in general; previously pesantren curriculum only studied the religious knowledge from kitab kuning as the only learning source, but the pesantren's curriculum now is beginning to learn general sciences from various sources as the modern school curriculum in general; formerly pesantren only use Arabic language in the education, but now using a lot of languages as other modern schools; even the latest phenomenon shows the existence of pesantren that accommodate entrepreneurship, so that pesantren's alumni have ability and skill to succed in the world and hereafter. Therefore pesantren as a traditional educational institution is able to accompany the dynamics of modern education development.

Pondok Pesantren as a typical Islamic education system in Indonesia is faced with the challenge of high divorce cases that result in the neglect of children. Although Duski Samad, et al stated that the high rate of divorce in West Sumatera is caused by the weakness of the role and function of the Agency for Counseling, Fostering, and Perpetuation of Marriage but it is only a small factor of $3 \%$, the rest is determined by other factors. ${ }^{33}$ Data Research Center of the Ministry of Religious Affairs of the Republic of Indonesia shows that out of two million married couples, 15 to 20 percent are divorced. Furthermore, it is known that the divorce cases that have

30 Mastuhu, Dinamika Sistem Pendidikan Pesantren: Suatu Kajian Tentang Unsur dan Nilai Sistem Pendidikan Pesantren (Jakarta: INIS, 1994).

31 Suyadi, "Mainstreaming the Knowledge of Islamic Education with Progress and of Islam Nusantara Education", Akademika 24, no. 1 (2019): 37-65.

32 Zamakhsyari Dhofier, Tradisi Pesantren: Studi Tentang Pandangan Hidup Kyai (Jakarta: LP3ES, 1987).

33 Us Kasful Anwar, "The Leadership of Kyai in Islamic Boarding School: a Study of Islamic Boarding School in Jambi". 
been decided by the High Court of Religion throughout Indonesia in 2014 reached 382.231, up approximately 131.023 cases compared to 2010 which is 251.208 cases. In fact, data from the Religious Courts of the Supreme Court said that in the last five years, the increase in divorce cases has reached 59 percent to 80 percent. Although every marriage has the values of Islamic education, ${ }^{34}$ when divorce occurs, these values also disappear.

Ahmad Tafsir explained that when in the family occurs disharmony, especially divorce or broken home, the first and the first victims are not the couples, but their children. ${ }^{35}$ Children of divorce family are vulnerable to troubled behavior as a result of emotional outbursts, because of the loss of their parents' love. Some study mentioned that the main perpetrators of juvenile delinquency (student brawl, free sex, drinking, etc.) at schools are broken home victims. In fact, public schools with good performance ${ }^{36}$ not necessarily capable of handling students' delinquency who have broken home background. Nursyamsi performs Islamic counseling on students in general, and the results are still diverse, ${ }^{37}$ but the subjects of counseling are not broken home students, but students in general. Moreover, at the pre-school level (Early Childhood Education), the management application has implications to the students' learning quality, ${ }^{38}$ not necessarily applicable to the early childhood of broken home victims.

In the midst of such a situation, pondok pesantren appear as the best alternative for them. The broken home children, who always

34 Al-Furqan, "Islamic Education Values in Minangkabau Wedding Ceremony: Study of Traditional Mariage in Pauh, Padang, West Sumatera", al-Ta'lim Journal 23, no. 1 (2016): 88-94.

35 Ahmad Tafsir, Ilmu Pendidikan dalam Perspektif Islam (Bandung: Remaja Rosdakarya, 2014).

36 Bianca De Wit, et al., "Neurogaming Technology Meets Neuroscience Education: a Cost-Effective, Scalable, and Highly Portable Undergraduate Teaching Laboratory for Neuroscience", Journal of Undergraduate Neuroscience Education (JUNE): a Publication of Faculty for Undergraduate Neuroscience (FUN) 15, no. 2 (2017): 104-9.

37 Nursyamsi, "Model of Islamic Counseling in Developing Students Competency in MAN 1 Bandung", al-Ta'lim Journal 22, no. 2 (2015): 107-19.

38 Rosniati Hakim, "Islamic Pre-School Management and Its Implications towards Students' Learning Quality Improvement”, al-Ta 23, no. 2 (2016): 114-27. 
make the commotion at school, can be subsided in pesantren. The existence of the Early Childhood Pesantren, including Baiquniyah may become an alternative in the community.

Normatively, Early Childhood Pesantren has a foundation in the Qur'an, which is Q.S. at-Tahrim [66]: 6. Through this ayah, Allah Almighty instructs the believers to keep themselves and their families from the fires of hell. ${ }^{39}$ One way to protect oneself and family from the fire of hell is to give a good religious education. One of the ways to give good religious education is sent a children to pesantren, such as Baiquniyah Early Childhood Pesantren. Thus, the existence of Baiquniyah Early Childhood Pesantren Yogyakarta corresponds to Q.S. at-Tahrim [66]: 6, and also has a role in protecting oneself and families from the fires of hell. However, some Hadiths precisely prohibit the existence of Early Childhood Pesantren. One of the reasons is that the 24 hour learning mechanism automatically separates children from parents, especially their mothers. Statement 1 below suggested three Hadiths which allegedly lead to the interpretation of the prohibition for Early Childhood Pesantren existence.

I heard the Messenger of Allah (peace and blessings be upon him) said, "Whoever causes separation between a mother and her child, then Allah will separate him from his beloved on the Day of Resurrection." (Transmitted by at-Tirmidhi, no. 1.283).

Indeed the Messenger of Allah forbids separating mother and her child. Someone asks him, "O Messenger of Allah, until when?" "Until reaching baligh when men and menstruate when women," replied Rasulullab sallallaabu 'alaibi wa sallam. (Transmitted by Hakim in his al-Mustadrak, sanad Hadith is sahih and not transmitted by al-Bukhari and Muslim).

A woman said, "O Messenger of Allah, this son of mine had my womb as a container, my breasts for drinking, my lap to contain him. But his father has divorced me and has taken him from me." The Prophet (peace and blessings be upon him) said, "You have more right if you do not marry (with others)." Abu Bakr said, "Ummu Ashim's scent,

39 Kementerian Agama RI, Al-Qur'an dan Terjemahannya (Jakarta: Kementerian Agama RI, 2010). 
her bed, and her lap are better for him than yours (Umar) until he grows up and chooses for himself." (Transmitted by Ahmad, Abu Dawud, and al-Hakim transmitted by Abdullah bin 'Amr).

Statement 1. Hadiths that forbid separating children from their parents.

Statement 1, which contained Hadiths quotations, is not talking about the Early Childhood Pesantren that separates the children from their mother, but talks about hadhanah, the children custody before mumazis when divorce occurs. Moreover, in the Compilation of Islamic Law Article 105 No.1 of 1.991 has been firmly stated that "Taking care of children who have not mumayyiz or not yet 12 years is the right of their mother." 40 Therefore, there is no reason to separate children with their mothers, including putting them into Early Childhood Pesantren.

Historically in social reality, many mothers do not want to take care of their children when divorce occurs, because they have a career to provide the children. Therefore, the problem is not the struggle for custody between father and mother, but custody of abandoned children. Their mother did not want to nurture, while their father had left both mother and children. Facing such a reality, the Child Protection Law provides a middle way alternative, in the article 14 of Child Protection Law stipulating that every child has the right to be cared for by his or her own parents, unless there is a valid legal reason and/or rule indicating that the separation is for children's best interests and is the last consideration. ${ }^{41}$

The term "separation" both in the Hadiths and the Child Protection Law can be interpreted both exoterically and esoterically. Esoterically, the term "separates" in the context of hadhanah is not as biological separation, but psychological separation. Therefore, even though the mother and children are biologically separated,

40 Arkola, Undang-undang Perkawinan di Indonesia (Surabaya: Arkola, 2001).

41 Syaifullah, Undang-undang Rumah Tangga No. 23 Tahun 2004 dan Undang-undang Perlindungan Anak No. 23 Tabun 2002 (Padang: Praninta Offset, 2008). 
they are both psychologically close. This also applies to the contrary, children who biologically near their mother are not necessarily close psychologically. The results of Nimade Herlinawati's research indicated that there is a new symptom of mothers who are often angry, threatening, and punishing her children. ${ }^{42}$ Nimade's research results can serve as a proof that children's can be closed biologically to their mother but separated psychologically.

The children's psychological closeness to their mother has the support of empirical data from the statement of a Baiquniyah santri, Rz (5 years old) on June 25, 2017 said that he went to the pesantren on his mother's orders. In addition, IMD always teaches children to pray for their parents, thus even when the parents are far away but still close to the heart. On this basis, IMD told the children that if there are children who miss their parents, then it is actually the parents who miss them. Thus, if both at-Tirmidhi and al-Hakim Hadiths are understood exoterically, then the Early Childhood Pesantren existence which biologically separates the children from their mother is no problem because they are psychologically close.

Based on the study of normativity and historicity of hadhanah Hadiths, the review of the Compilation of Islamic Laws, and considering the Child Protection Law, it is understood that "separation" can be done with the consideration that separation is the best interest and the last option. This separation is including send the children into Early Childhood Pesantren. If putting children into Early Childhood Pesantren is for the sake of the children, and also as the last consideration-rather than the children being deposited to their old grandparents, or to the orphanage and other social institutions- then the Early Childhood Pesantren is the best and last option.

42 Nimade Herlinawati, "Perilaku Agresif pada Remaja Putri yang Mengalami Abuse Oleh Ibu”, Fakultas Psikologi Universitas Gunadarma Yogyakarta, 2016. 


\section{Alternative Pondok Pesantren}

Most of the Baiquniyah Children Pesantren's santri are broken home victims, such as divorced parents, left behind to work overseas, unclear child status (their parents are unknown), and so on. This was directly addressed by the leader of the Baiquniyah Children Pesantren Yogyakarta, K.H. Imadudin, as shown in statement 2 as follows:

"Most of the children here have problematic parents. If not divorced then separated; one parent being woman labor abroad, the other works in big cities, such as Ln's parents, his parents are separated but still in the country; her mother in Java while her husband in Borneo. They will visit every month in turn. But for those who work abroad, their child only visited once a year. There is even a child who for two years is not visited because their parents are not clear." 43

The same thing is also acknowledged by one of the Baiquniyah children, (Rz: 6 years old) who said that his mother is in Solo, Central Java but his father is in Lampung, South Sumatra. Although both $\mathrm{Rz}$ parents are still together, because live apart, it is vulnerable to disharmony. Various studies show that the whole family (children have both father and mother that still together) but are separated from each other, then the family is susceptible to divorce. Research conducted by Atika Widayanti ${ }^{44}$ and Suyadi ${ }^{45}$ showed that the relationship of women who have a career abroad as women labor are vulnerable to divorce due to factors of economic, communication, and faithfulness. ${ }^{46}$ The study also states that one of the negative

43 Interview with IMD, caretaker of Baiquniyah Early Childhood Pesantren Yogyakarta on Sunday, May 14, 2017 at 12.30 at Baiquniyah Early Childhood Pesantren Yogyakarta.

44 Atika Widayanti, "Faktor-faktor Penyebab Perceraian pada Keluarga Tenaga Kerja Wanita (TKW) di Desa Citembong, Kecamatan Bantarsari, Kabupaten Cilacap", Universitas Negeri Yogyakarta, 2014.

45 Suyadi, "Diferensiasi Otak Laki-laki dan Perempuan Guru Taman Kanakkanak Aisyiyah Nyai Ahmad Dahlan Yogyakarta: Studi Pendidikan Islam Anak Usia Dini Perspektif Gender dan Neurosains", Sawwa: Jurnal Studi Gender 13, no. 2 (2018): 179-202.

46 Atika Widayanti, "Faktor-faktor Penyebab Perceraian pada Keluarga Tenaga Kerja Wanita (TKW) di Desa Citembong, Kecamatan Bantarsari, Kabupaten Cilacap", Universitas Negeri Yogyakarta, 2014. 
effects of divorce is that children are unruly because it is only close to one of their parents. ${ }^{47}$ In an interview on May 14, 2017, IMD stated that when calculated, there are more than $80 \%$ of Baiquniyah santri are came from divorced families, $10 \%$ of harmonious families who want to make their children as hafidz/ hafidzah (memorizing the Qur'an), and 10\% other from the family less harmonious as stated by Rz.

The above interview data quote should be interpreted appropriately, that although most of the children santri are broken home victims, it does not mean that Early Childhood Pesantren is a "dumping" place for troubled children. Precisely if troubled children can be educated to be good children (shalih and shalihah), then nonproblematic children will be easier to be educated for the better. Similar case happens to Montessori schools that initially reserved for children with special needs, but the reality shows that even normal children can grow and develop better. Thus, if the pesantren is able to fix the morals or character of the troubled children who are broken home victims, then the Early Childhood Pesantren is easier to form children's character that is not broken home victims.

A Baiquniyah santri, St (6 years old) in an interview on December 6, 2017 said that "I come here for my own sake; I want to memorize the Qur'an". When St was visited by his parents together (just call them as Imran and Aisyah), in interviews on the same day and same date (Sunday, December 6, 2017) they said that their child's desire to enter pesantren can't be prevented. Both parents of St said, "St entered the pesantren because of his own will. We can not prevent him. But we are still happy because it has become his goal." This fact, that at the same time becomes important data, is an irrefutable argument that the Baiquniyah Early Childhood Pesantren is not a place for "dumping" troubled children.

47 Suyadi, "Pendidikan Islam Anak Usia Dini dalam Perspektif Neurosains: Robotik Akademik dan Saintifik", Edukasia: Jurnal Penelitian Pendidikan Islam 13, no. 2 (2018): 231-62. 
Early Childhood Pesantren is the best and last alternative choice for children, as one of the santri's guardians (guardian of Rz: 6 years old), Ms. Hn said that if her child is given to grandparents it will just add burden to them; but if put to an orphanage, the child is not an orphan; even more so if put into full-time school, Hn herself also can not take care of him, hence Early Childhood Pesantren is the last choice.

Based on the statement of Ms. Hn, it can be seen that Early Childhood Pesantren is the final best alternative for her child. Therefore, put the children of broken home victims into the Early Childhood Pesantren is the right decision. Muhammad Najib Azca, Director of Youth Studies Center UGM at Forum Group Discussion in Unit I Building of Pemkab Sleman, Thursday, March 17, 2017 said that the phenomenon of juvenile delinquency, especially klitih (vandalism and random attack) in Yogyakarta that was rampant in 2017, turns out that they are children of broken home victims (divorce and disharmony). In fact, the rate of divorce in Indonesia is increasing from year to year.

The writer argues that troubled children are more effective in being educated in the pesantren rather than in general schools and madrasah. A number of studies showed that children who have problems at home, including broken home victims, always make the commotion in school. In fact, most perpetrators of motorcycle gank, student brawl, klitih, free sex, drug abuse, and so forth are children with the bad family background. However, once again, it should be emphasized that even though the problematic children are more appropriately educated in pesantren, it does not mean that pesantren is the education_-dumping-place for problematic children.

\section{Paedagogical Psychology Immunity}

In the previous discussion, it has been explained that the Early Childhood Pesantren normatively becomes the last and best option, especially for children of broken home victims, and generally for 
early childhood education in the modern era. The next issue that needs to be answered is the gap between modern educational psychology theories and the practice of education at Baiquniyah Early Childhood Pesantren. Modern educational psychology theory said that children still need more affection hugs from parents because they are still vulnerable to changing situations thus easily depressed. Furthermore, modern education theory mentioned that the one responsible for education is family. The problem is, how can Baiquniyah Early Childhood Pesantren run without referring to modern educational psychology theories? By means of the same fieldwork in answering the first question above, here is a discussion of the problem.

Psychologically, early childhood still needs more closeness even hugs from parents, especially mothers. According to research conducted by researchers team from the University of Bologna Italy, early childhood is susceptible to depression when they face an uncertain environmental change. ${ }^{48}$ In this case, parental hugs are more effective at reducing depression than antidepressants. Also, depressed children who are then given anti-depressants showed a tendency to regain higher levels of depression. Another study explained that the myths about children who are often hugged by their parents will become whiny children is wrong, on the contrary, they grow as a loving person and have the high sense of self-confidence. This is a general theory, not necessarily specific, especially for children in pesantren.

Research conducted by Siti Mumun Muniroh stated that the psychological condition of early childhood santri is influenced by the pattern of care in the pesantren. Authoritarian care pattern with many penalties imposed; such as being beaten, locked up, being flushed, and so on, has no significant effect on the children's development

48 Imam Suyono, "Jangan Asramakan Anakmu”, Republika.Co.Id (Jakarta, 2016). 
of cognition, emotion, and even psychosocial ${ }^{49}$. It is because only the students who violate the discipline are punished, while those who are obedient, comply, ${ }^{50}$ discipline, and appreciate the time ${ }^{51}$ can still be free to play and learn.

This research reinforces Siti Mumun Munirof's research by showing facts and data that the early childhood santri in Baiquniyah Early Childhood Pesantren Yogyakarta have high pedagogical psychological immunity (mental immunity in learning) thus they can survive from depression and even stress for years without hugs from their parents. Their psychological immunity has been tested for a long time with evidence that they continuing primary and secondary education, which is Madrasah Ibtidaiyah (Islamic Elementary School) and Madrasah Tsanawiyah (Islamic Junior High School) in the pesantren. Moreover, there is a tendency that the students at Baiquniyah Early Childhood Pesantren Yogyakarta feel more comfortable in pesantren with their ustadz rather than at home with their parents. On this basis, the researcher calls it with the theory of pedagogical psychology immunity; strengthening the children's mental endurance to deal with changes in the unstabilized situation, thus they feel comfortable and happy.

There are at least three mechanisms of pedagogical psychological immunity applied by the Baiquniyah Early Childhood Pesantren Yogyakarta. The three mechanisms of pedagogical psychological immunity are: (a) adaptation in the first 40 days, (b) Kyai as the second psychological parents, (c) emotional manipulation. Here are three forms of mechanisms of pedagogical psychology immunity.

49 Siti Mumun Muniroh, "Psikologi Santri Usia Dini”, Jurnal Penelitian 11, no. 1 (2014): 146-71.

50 Anita Dwi Rahmawati, "Kepatuhan Santri terhadap Aturan di Pondok Pesantren Modern”, Program Magister Psikologi, 2015.

51 Dinasril Amir, "On Time and Discipline in Islam: Analysis towards Purpose of Islamic Education”, Leadership 21, no. 3 (2014): 220-26. 


\section{a. Adaptation in the First 40 Days}

The first mechanism that makes early childhood santri survive in pesantren is those who can pass the adaptive experimentation during the first 40 days. Indeed, theoretically early childhoods are not the time to part with their parents, including not the time to enter pesantren. But according to IMD, when parents are able to prepare the children's mental (psychological age) that they are willing or accept themselves to study at the pesantren, then as early as any age of the children, they can be separated from parents and enter the pesantren. Conversely, if parents fail to prepare children's mental condition to enter pesantren, then even in adulthood (biological age) they are not ready to enter the pesantren. Thus, the children's readiness age benchmark is not a biological age, but a psychological age.

The question is how to measure the people's psychological age in which they are ready to enter the pesantren? In this case, IMD uses the 40 days parameter as the experimentation of children ready or not to be in pesantren. It means every child who comes to pesantren must take adjustment or adaptation period for 40 (forty) days. During those 40 days, any santri, regardless of age, should not be visited by both parents. If for 40 days the child survives in the pesantren without being visited by parents, then certainly the child will survive in pesantren forever. Conversely, if before 40 days the child asks to go home or parents to visit him, it is certain that he will not last long in the pesantren. IMD said as in statement 3 below:

\footnotetext{
"Every new santri, in the first 40 days should not be visited to see if he is ready and able to stay at the pesantren. If the child is not able to survive, then we will call back the parents to take back their child and bring him here after the child is really ready and the parents are really willing." 52
}

Based on IMD description, it is clear that between parents and children should have a shared commitment; children want to

52 Interview with IMD, caretaker of Baiquniyah Early Childhood Pesantren Yogyakarta on Sunday, May 14, 2017 at 12.30 at Baiquniyah Early Childhood Pesantren Yogyakarta. 
be put into the pesantren and parents willing to send their children to pesantren. That is, the intention of entering the pesantren can not be just one-sided, the parents force children into pesantren or vice versa, the children impose parents to go to pesantren. Therefore, disagreement will disrupt the learning process in pesantren.

Throughout the first 40 days, the pesantren has prepared a number of learning programs for santri, from waking up to going back to sleep, including arranging children's sleep hours. The tight schedule mechanism of this learning program is designed so as not to leave emptiness or loneliness ${ }^{53}$ in children's hearts, that make them want to return to their parents at home.

According to habituation theory, repeated habits, in the long run, will change the mindset and create new habits. ${ }^{54}$ From this theory, it can be understood that children habits in learning together without their parents' hugs for 40 days has changed the mindset and gave birth to new habits of life in pesantren so that they are no longer experience dependency in loving embrace or feel homesick biologically to their parents. Thus, it can be concluded that the readiness to enter the pesantren is determined by parents and children mental agreements that can be measured during the first 40 days in the pesantren without meeting each other.

\section{b. Kyai as Psychological Parents}

The second mechanism in Baiquniyah Early Childhood Pesantren that conditioned the early childhood santri to survive in Pesantren without being dependent on the parents' hugs is the love and care of Kyai and ustadz, who are much gentler than the "embrace" of their parents" affection. In other words, Kyai and $u s t a d z$ as caretakers and board members are educating their santri as they educate their own children and families. This shows that

53 Dwi Sona, "Mengidentifikasi Kesepian pada Anak Pondok Pesantren dengan Menggunakan Children Loneliness Scale", Makalah, Seminar Psikologi dan Kemanusiaan, Psychology Forum Universitas Muhammadiyah Malang, 2015.

54 H.A. Rodli Makmun, "Pembentukan Karakter Berbasis Pendidikan Pesantren: Studi di Pondok Pesantren Tradisional dan Modern di Kabupaten Ponorogo", Cendekia 12, no. 2 (2014). 
Kyai and ustadz in Baiquniyah Early Childhood Pesantren are not only acting as Kyai and administrators, but also as "psychological parents" who function both as substitute parents and second parents. This reality reinforces Rizki Setiawan's research stated that there is no relationship between the wage or salary of Kindergarten teachers with creativity, ${ }^{55}$ as there is no relationship between Baiquniyah ustadis love with the small salary, thus learning impressed full of blessings, not money transaction.

IMD in an interview on Sunday, May 21, 2017 said, "I educate the santri as I educate my own children." This statement showed that Kyai in Baiquniyah Early Childhood Pesantren Yogyakarta not only acts as charismatic pesantren caretaker that needs to be respected, but also a father for the children who always love the children. The caretaker's statement was strengthened by the words of one of the ustadz at the pesantren (Im: 24) stated, "I am the eldest brother for the younger siblings here." This brief statement showed that ustadz at Baiquniyah Early Childhood Pesantren do not prioritize the seniority relationship, but rather emphasizes the brotherhood solidarity.

Based on the information of IMD and one of the ustadz. (Im) in Baiquniyah Early Childhood Pesantren, it can be understood that early childhood santri can survive without parents hugs because of Kyai and ustadz able to act as a substitute for their parents that they accept wholeheartedly. This data can counter Finkelhor and colleagues' research that in boarding schools (Pesantren) childcare is carried out without violence, very different from children cared for by caregivers who have been prone to violence. ${ }^{56}$

There is a compelling reason why early childhood santri accept Kyai and Ustadz as psychological parents. The reason is that most of santri's parents - especially them with the broken home background-just give minimal affection. In fact, they behave less

55 Risky Setiawan, "The Influence of Income, Experience, and Academic Qualification on the Early Child Hood Education Teachers' Creativity in Semarang, Indonesia", International Journal of Instruction 10, no. 4 (2017): 39-50.

56 Finkelhor, at al., "Child Maltreatment Rates Assessed in a National Household Survey of Caregivers and Youth", Child Abuse and Neglect 38 (2014), 1.421-1.435. 
well to their own biological children that they "throw them" into the pesantren. According to HB (6 years old), a santri of Baiquniyah Early Childhood Pesantren, in an interview on Sunday, November 12, 2017 stated, "I was told by my mother to come here so as not to be a rebellious demon." This HB statement is very startling because it indicates that he was not being treated with affection at home, as described in the ideal psychological theories. The term "demon" that her mother pointed out indicates that her mother matches HB (her own child) with a bad creature worse than a beast. This data is in accordance with Tucker's research which states that children in disharmonious families experience conflict more often. ${ }^{57}$

Parents' attitudes and behaviors that are disharmonious and then "throw" their children into pesantren lead to negative stigma about pesantren. Pesantren which should be understood as a place to gain knowledge and forming the noble character is only understood as a place for troubled children "disposal". Mischievous children of broken home victims are thrown into the pesantren in the hope of becoming sholih and sholihah (good character) children. This stigma should be straightened out little by little, in order to pesantren back into excellent educational institutions that receiving santri from troubled families, as well as santri from harmonious families in general. This openness is clearly different from general education institutions that openly does not accept the problematic students, or will drop out troubled learners. In here is the pesantren's prominence, which is ready to accept the challenges of the era.

\section{c. Emotional Manipulation}

The third mechanism that makes early childhood santri able to survive in pesantren without parents hug is emotional manipulation. Emotional manipulation is the transfer of children's feelings from certain conditions to other conditions. ${ }^{58}$ For example, when children

57 Tucker, at. al., "Family Dynamics and Young Children's Sibling Victimization", Journal of Family Psychology 28, no. 5 (2014): 625-633.

58 Suyadi, "The Synergy of Arts, Neuroscience, and Islam In Early Chilhood Learning in Yogyakarta", Tarbiya: Journal of Education in Muslim Society 5, no. 1 (2018): 30 42. 
occasionally feel the longing to meet their parents, the ustadz then diverts the children's attention to other things that the children prefer (playing, for example), so they forget the longing feeling.

This kind of incidents is often experienced during the first 40 days of adaptation. Therefore these incidents occasionally still appear in the next period of time with much less intensity. Bm (6 years old), a santri from Bengkulu when interviewed on Sunday, November 12, 2017 was questioned, "What to do when missing parents?" He replied lightly, "Maybe teary or want to cry." Im, an $u s t a d z$ in an interview at the same time adds, "Even though a child cries to meet his parents, but if being entertained by friends to play or doing sport then he will forget by himself." This reality is in accordance with the theory of adolescent psychology which stated that peer influence is stronger than the parents' advice. ${ }^{59}$ Observing the information from the santri and ustadr, it is clear that the environment is quite influential on the children's happiness so that they feel more comfortable in the pesantren than at home.

The emotional manipulation that supported by the pleasant environment of peers is effective enough to be psychological therapy for the early childhood santri to survive in the pesantren in a fun way. $\mathrm{Hb}$ admitted that he is happier in the pesantren, because in pesantren he has many friends while at home he has no friends.

Therefore, it can be concluded that the learning process in Baiquniyah Early Childhood Pesantren can be run without fully referring to modern educational psychology theories, because the Baiquniyah Early Childhood Pesantren has formed a pedagogical psychology immunity of santri with three educative mechanisms, which are: the first 40 days adaptation, Kyai as psychological parents, and emotional manipulation. All three are running in a regulative way, so without the parents' hugs and affection, early childhood santri can survive from depression and stress.

59 Imam Zarkasih Putro and Suyadi, Bimbingan dan Konseling Pendidikan Anak Usia Dini (BK-PAUD) (Bandung: Remaja Rosdakarya, 2016). 


\section{Conclusion}

The Baiquniyah Early Childhood Pesantren Yogyakarta that is normatively incompatible with some Hadiths, especially the Hadiths of at-Tirmidhi and al-Hakim which stated that early childhood should not be separated from their parents, after historically reviewed-especially children of broken home victims- Early Childhood Pesantren bring psychological closeness of children and parents through rituals and prayers. In other words, Early Childhood Pesantren actually brings the children closer to their parents psychologically, even though the two are biologically apart. Moreover, Early Childhood Pesantren would be the last alternative choice that provides the best pedagogical psychology services for children. This is not to means that Early Childhood Pesantren is only for the broken home children, because there are children who want to become hafidz-hafidzah early in life, thus motivate them to go to pesantren from an early age.

Theoretically, children who are separated from their parents, thus rarely get the affectional hug from parents to have potential to experience depression due to uncertain environmental changes. But in reality the early childhood santri in Baiquniyah Early Childhood Pesantren Yogyakarta can survive from depression for many years, there is even tendency of children more happy and comfortable in Pesantren than in their own home. This suggests that santri at the Baiquniyah Pesantren Yogyakarta have paedagogical psychological immunity (mental endurance in learning) to emotional storms, especially depression due to the lack of hugs of parental affection. This immunity is formed because of the three pedagogical psychology mechanisms run by the Baiquniyah Early Childhood Pesantren, which are: the first 40 days adaptation, the role of Kyai as the second psychological parents, and emotional manipulation.

This study recommends subsequent researchers to do an indepth investigation on the learning programs forms of adaptation during the first 40 days for new santri that not yet revealed in this 
Suyadi

research. In addition, it is necessary to further investigate the potential of emotional therapy for the santri who can not survive in the Baiquniyah Early Childhood Pesantren Yogyakarta. Finally, if possible, the rote learning model should be studied in the perspective of thinking science (neuroscience), not psychology as used in this research. 


\section{REFERENCES}

Amir, Dinasril. "On Time and Discipline in Islam: Analysis towards Purpose of Islamic Education”, Leadership 21, no. 3 (2014).

Amran, Ali. "Pengembangan Kecerdasan Spiritual Anak Usia Dini Berbasis Edutainment di TK Qurrota A'yun Pondok Pesantren Anak Bantul Yogyakarta”, Universitas Islam Negeri (UIN) Sunan Kalijaga Yogyakarta, 2015.

Arkola. Undang-undang Perkawinan di Indonesia. Surabaya: Arkola, 2001.

Azra, Azumardi. Pendidikan Islam: Tradisi dan Modernisasi Menuju Milineum Baru. Bandung: Mizan, 2012.

Binti Su'aidah Hanur, Fatimah. "Dari Pesantren untuk PIAUD: Relevansi Pemikiran al-Ghazali dengan Prosesi Pendidikan Islam Anak Usia Dini di Era Modern”, Annual Conference for Muslim Scholars Kopertais Wilayah IV Surabaya (ANCOMS) 2017.

Chusniyah, Siti, and Moh. Yasir Alimi. "Nyai Dadah: the Elasticity of Gender Roles and Life", Jurnal Komunitas 7, no. 1 (2015).

Dhofier, Zamakhsyari. Tradisi Pesantren: Studi Tentang Pandangan Hidup Kyai. Jakarta: LP3ES, 1987.

Finkelhor, at al. "Child Maltreatment Rates Assessed in a National Household Survey of Caregivers and Youth", Child Abuse and Neglect 38 (2014).

al-Furqan. "Islamic Education Values in Minangkabau Wedding Ceremony: Study of Traditional Mariage in Pauh, Padang, West Sumatera”, al-Ta'lim Journal 23, no. 1 (2016).

Hakim, Rosniati. "Islamic Pre-School Management and Its Implications towards Students' Learning Quality Improvement", al-Ta 23, no. 2 (2016).

Herlinawati, Nimade. "Perilaku Agresif pada Remaja Putri yang Mengalami Abuse Oleh Ibu", Fakultas Psikologi Universitas Gunadarma Yogyakarta, 2016. 
Hidayat, Ade. "Peaceful in Pesantren: the Involvement of Santri's Peaceful Environment and Personality", al-Ta'lim Journal 24, no. 2 (2017).

Kementerian Agama RI. Al-Qur'an dan Terjemabnya. Jakarta: Kementerian Agama RI, 2010.

Khorij. "Pendidikan di Pesantren: antara Mempertahankan Tradisi dan Kebutuhan Modernisasi”, Manhaj 4, no. 1 (2011).

Makmun, H.A. Rodli. "Pembentukan Karakter Berbasis Pendidikan Pesantren: Studi di Pondok Pesantren Tradisional dan Modern di Kabupaten Ponorogo", Cendekia 12, no. 2 (2014).

Mastuhu. Dinamika Sistem Pendidikan Pesantren: Suatu Kajian Tentang Unsur dan Nilai Sistem Pendidikan Pesantren. Jakarta: INIS, 1994.

Muniroh, Siti Mumun. "Psikologi Santri Usia Dini”, Jurnal Penelitian 11, no. 1 (2014).

Musaropah,Umi. "PemberdayaanMasyarakatdalamPenyelenggaraan Pendidikan Anak Usia Dini Berbasis Pesantren", as-Sibyan: Jurnal Pendidikan Guru Raudlatul Athfal 1, no. 2 (2016).

Nursyamsi. "Model of Islamic Counseling in Developing Students Competency in MAN 1 Bandung", al-Talim Journal 22, no. 2 (2015).

Putra, Hermansyah. "Pondok Pesantren dan Tantangan Globalisasi: Upaya Pondok Pesantren Musthafawiyyah Purba Baru Sumatera Utara dalam Mempertahankan Sistem Tradisional", Universitas Islam Negeri (UIN) Sunan Kalijaga Yogyakarta, 2009.

Rahmawati, Anita Dwi. "Kepatuhan Santri terhadap Aturan di Pondok Pesantren Modern", Program Magister Psikologi, 2015.

Setiawan, Risky. "The Influence of Income, Experience, and Academic Qualification on the Early Child Hood Education Teachers, Creativity in Semarang, Indonesia", International Journal of Instruction 10, no. 4 (2017). 
Sona, Dwi. "Mengidentifikasi Kesepian pada Anak Pondok Pesantren dengan Menggunakan Children Loneliness Scale", Makalah, Seminar Psikologi dan Kemanusiaan Psychology Forum Universitas Muhammadiyah Malang (UMM), 2015.

Steenbrink, Karel A. Pesantren Madrasah Sekolah. Jakarta: LP3ES, 1986.

Supriadi. "Leadership in Islamic Education Institution", Leadership 21, no. 3 (2014).

Suyadi. "Diferensiasi Otak Laki-laki dan Perempuan Guru Taman Kanak-kanak Aisyiyah Nyai Ahmad Dahlan Yogyakarta: Studi Pendidikan Islam Anak Usia Dini Perspektif Gender dan Neurosains”, Sawwa: Jurnal Studi Gender 13, no. 2 (2018).

. "Mainstreaming the Knowledge of Islamic Education with Progress and Islam Nusantara Education", Akademika 24, no. 1 (2019).

- "Pendidikan Islam Anak Usia Dini dalam Perspektif Neurosains: Robotik Akademik dan Saintifik", Edukasia: Jurnal Penelitian Pendidikan Islam 13, no. 2 (2018).

. "The Synergy of Arts, Neuroscience, and Islam in Early Chilhood Learning in Yogyakarta", Tarbiya: Journal of Education in Muslim Society 5, no. 1 (2018).

Suyadi and Maulidya Ulfa. Konsep Dasar PAUD. Bandung: Remaja Rosdakarya, 2013.

Suyadi dan Imam Zarkasih Putro. Bimbingan dan Konseling Pendidikan Anak Usia Dini (BK-PAUD). Bandung: Remaja Rosdakarya, 2016.

Suyadi, Sutrisno. "A Genealogycal Study of Islamic Education Science at the Faculty of Ilmu Tarbiyah dan Keguruan UIN Sunan Kalijaga", al-Jami'ab: Journal of Islamic Studies 56, no. 1 (2018).

Suyono, Imam. "Jangan Asramakan Anakmu", Republika.Co.Id., 2016.

Syaifullah. Undang-undang Rumah Tangga No. 23 Tahun 2004 dan 
Undang-undang Perlindungan Anak No. 23 Tahun 2002. Padang: Praninta Offset, 2008.

Tafsir, Ahmad. Ilmu Pendidikan dalam Perspektif Islam. Bandung: Remaja Rosdakarya, 2014.

Tucker, at al. "Family Dynamics and Young Children's Sibling Victimization", Journal of Family Psychology 28, no. 5 (2014).

Us, Kasful Anwar. "The Leadership of Kyai in Islamic Boarding School: a Study of Islamic Boarding School in Jambi", Leadership 22, no. 1 (2001).

Widayanti, Atika. "Faktor-faktor Penyebab Perceraian pada Keluarga Tenaga Kerja Wanita (TKW) di Desa Citembong, Kecamatan Bantarsari, Kabupaten Cilacap", Universitas Negeri Yogyakarta, 2014.

Wit, at al. "Neurogaming Technology Meets Neuroscience Education: a Cost-Effective, Scalable, and Highly Portable Undergraduate Teaching Laboratory for Neuroscience", Journal of Undergraduate Neuroscience Education (JUNE): a Publication of Faculty for Undergraduate Neuroscience (FUN) 15, no. 2 (2017).

Yuliani, Nelpa Fitri. "Hubungan antara Lingkungan Sosial dengan Motivasi Belajar Santri di Pesantren Madinatul Ilmi Islamiyah", Spektrum PLS 1, no. 2 (2013). 